
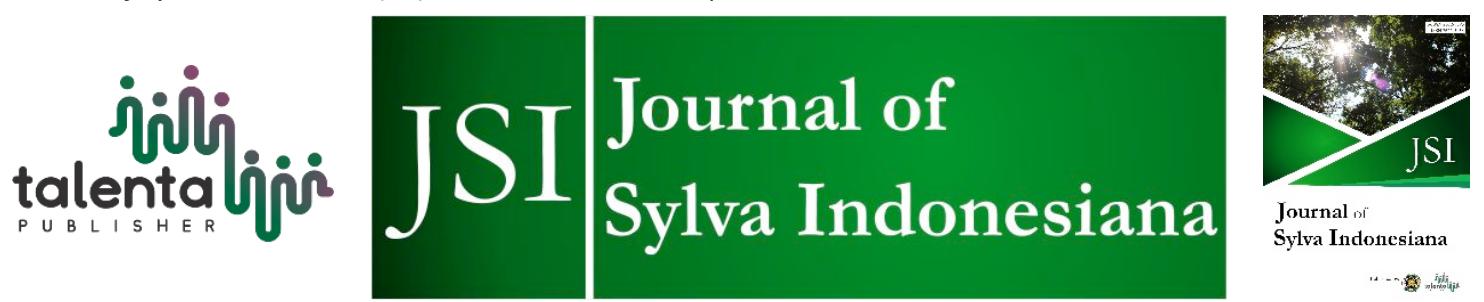

\title{
Saga (Adenanthera pavonina Linn) Seeds Milk As an Alternative Source of Protein from Tree Species
}

\author{
Novia Dwitanti ${ }^{1}$, Ridwanti Batubara ${ }^{1 *}$, Elisa Julianti ${ }^{1}$, Latifah Hanum ${ }^{1}$, \\ and Wulan Syahputri ${ }^{1}$
}

${ }^{I}$ Faculty of Forestry, University of Sumatera Utara, Jl. Tri Dharma Ujung 20155 Medan, Sumatera Utara, Indonesia

\begin{abstract}
Saga seeds derived from saga (Adenanthera pavonina Linn) trees belong to the family Fabaceae (Leguminosae-Mimosaceae) and have potential as a protein source. This research aims to obtain information about saga seeds milk's potential as alternative milk based on processing and flavor enhancements. The test method for saga seed milk protein was the determination of N-Total using the Kjeldahl Semi Micro method. The consumer preference level test is carried out with a hedonic analysis based on the color, aroma, and taste parameters. The saga seeds milk protein test results with the addition of $150 \mathrm{~mL}$ of water and cooking time for 10 minutes contain protein levels $1.19 \% \pm 0.16$. Organoleptic test results showed that saga seeds milk with the addition of $200 \mathrm{~mL}$ of water, cooked for 10 minutes with strawberry flavor had the highest score with an average color of $3.72 \pm$ 0.94 , aroma $3.96 \pm 0.90$ and taste $3.96 \pm 0.90$.
\end{abstract}

Keyword: Organoleptic Test, Protein, Saga Seeds (Adenanthera pavonina)

Received 29 June 2020 | Revised 24 July 2020 | Accepted 26 August 2020

\section{Introduction}

As a tropical country, Indonesia is an excellent habitat to grow and develop flora and fauna. Forests are increasingly limited to being used as sources of wood because, currently, the forest area is reduced. In contrast, the development of non-timber forest products (NTFPs) continues to be developed. NTFPs produce several products, such as fruits, animals, medicinal plants, and environmental services. The saga (Adenanthera pavonina L.) tree is one of the NTFPs that can be utilized. Saga is an exotic native tree from Asia, belongs to the family Fabaceae [1] and endemic to Southern China and India [2]. Saga tree is a versatile plant; all parts of this plant are useful, ranging from seeds, wood, bark, and leaves. Saga is an important medicinal plant from

\footnotetext{
*Corresponding author: Faculty of Forestry, University of Sumatera Utara, Jl. Tri Dharma Ujung 20155 Medan, Sumatera Utara, Indonesia

E-mail address: ridwantibb@yahoo.com
} 
the Indian subcontinent. Saga has been used as traditional herbal medicine to treat various diseases [3].

Saga is producing fruit similar to petai fruit (pod type) with small seeds vivid scarlet [4]. Saga trees can produce seeds rich in protein and do not require special requirements for growing places because they can grow in degraded land and do not require fertilization or intensive care. Besides, pests and weeds are minimal, so that they do not need pesticides. Saga also environmentally friendly because it can be planted with other plants. Saga is usually used as a shade tree on major roads [5].

In the past decade, saga seeds were used as weighing gold because of their constant weight. Saga seeds that are roasted on fire are eaten by children and adults [6]. Seeds contain fatty acids, so they can be an alternative energy source (biodiesel). The leaves are edible and contain alkaloid compounds that are efficient for rheumatic healing. Saga bark extract contains antibacterial compounds that can inhibit bacterial growth with various effectiveness. Antibacterial from plant extracts is generally used by the people no less effective than modern medicine even more economical and safe to use as a drug [7].

Protein is a food substance that is very important because this substance being a source of energy as well as has functioned as substance builders and regulators in the body. Milk is a significant source of protein and the main source of nutrition for babies before they can digest solid food. So far, the types of milk consumed by humans come from animals such as cows, goats, and camels or derived from beans such as soy and mungbean [8].

Saga seeds contain protein and crude fat [9] in $2.44 \mathrm{~g} / 100 \mathrm{~g}$ and $17.99 \mathrm{~g} / 100 \mathrm{~g}$. It also contains low sugar $(8.2 \mathrm{~g} / 100 \mathrm{~g})$, starch (41.95 g/100 g), and carbohydrates [10]. The protein content in saga seed extract is high compared to other legume plants. Therefore this plant is potentially used as a source of protein that can be consumed by humans. Saga seed can be extracted and made to become milk. Saga seed milk contains a protein that can meet the community protein requirement [9].

The limit amino acids in saga seed are methionine and cysteine, a type of amino acid found in low levels. At the same time, total fatty acids, linoleic, and oleic acids are around $70.7 \%$. The free fatty acids content of saga seed is relatively high. The peroxide and saponin content of saga seeds are $29.6 \mathrm{mEqkg}$ and $164.1 \mathrm{mgKOHg}$, respectively. This shows the similarity of oil content in food [10]. Saga seeds also contain protein trypsin inhibitors [11].

Food processing conditions such as temperature will affect the nutritional content. In the extraction process, an increase in temperature will increase the percentage of protein, fat, and carbohydrates that are extracted. The right temperature is needed to maintain the protein content and other processed food [13]. On the other hand, the saga milk has an unpleasant taste. 
Therefore, efforts are made to reduce the unpleasant taste by adding natural flavorings, such as fragrant pandan leaves [14]. This study aims to determine the effect of processing and flavor addition on physical and chemical quality and consumer preference of saga seeds milk.

\section{Research Method}

\subsection{Seed Samples and Making Saga Milk}

The mature and shiny red of saga seed was collected from the saga tree at the Universitas Sumatera Utara, Medan. Saga seeds are coated with very hard skin, lens-shaped, vivid scarlet, and adhere to the pods [10].

\subsection{Making Saga Seeds Milk and Saga Seeds Protein Content Analysis}

About $50 \mathrm{~g}$ dried saga seeds were washed using clean water and then boiled by adding the water for 10 and $15 \mathrm{~min}$. The boiled saga seeds husk were removed using a pressure of two hands and cleaned with fresh water. The clean dehulled saga seed was ground by adding water 150, 200, and $250 \mathrm{ml}$ until the saga pulp was obtained. The saga pulp was then cooked until boiling and filtered using a delicate cloth to separate milk from residue. Saga milk was then cooled and put into a sterilized bottle and stored at $10^{\circ} \mathrm{C}$ for three days before analysis. The protein content was analyzed using the Semi-Micro Kjeldahl N-Total Method.

\subsection{Viscosity Test}

Viscosity is a measure of the resistance of a liquid to flow. Saga milk viscosity tests are carried out using a Brookfield viscometer according to [15] method.

\section{$2.4 \quad$ Organoleptic Test}

Organoleptic tests are tests that measure the level of consumer preferences for food or drinks [16]. Thirty panelists from different ages carried out the organoleptic analysis of saga milk. The panelists evaluated the saga milk samples using 5 points hedonic scale method from 5 (like extremely) to 1 (dislike immensely). The organoleptic attributes valued were color, aroma, and flavor.

\section{Results and Discussion}

\subsection{Protein Content}

The effect of cooking time and the amount of water added in making saga seed milk on the protein content can be seen in Table 1. The longer the cooking time and the more water added, the lower the saga milk protein content. The protein content of saga seed milk was $0.37-1.19 \%$, which was lower than soybean milk. According to [17], the protein content of soya milk was $2.53 \%-4.43 \%$. 
Table 1 The effect of cooking time and the amount of water added in making saga seed milk on protein content

\begin{tabular}{cccc}
\hline \multirow{2}{*}{ Cooking time (min) } & \multicolumn{3}{c}{ Amount of water added (ml) } \\
\cline { 2 - 4 } & 150 & 200 & 250 \\
\hline 10 & $1.19 \pm 0.16$ & $0.66 \pm 0.09$ & $0.37 \pm 0.12$ \\
15 & $0.82 \pm 0.18$ & $0.45 \pm 0.04$ & $0.38 \pm 0.17$ \\
\hline
\end{tabular}

All values are means with \pm standard deviation $(n=3)$

Although saga seeds milk's protein content is lower than soya milk, saga seeds milk can be used as an alternative vegetable protein. Vegetable protein is a protein derived from various nuts, different from animal protein derived from animals. Therefore, these two sources of protein must be consumed to meet daily protein needs.

Research conducted [18] showed that the best saga milk protein content was $3.81 \%$, achieved by treatment at $70^{\circ} \mathrm{C}$ with a ratio of water volume and weight of saga 1: 1 . The more water is added, the smaller the measured protein content. This study shows that the amount of water affects the milk protein content.

Based on the analysis of variance at the $95 \%$ confidence level, it shows that the amount of water and cooking time has a significant effect on the milk protein content of saga seeds. It proves that saga seeds milk's protein content from all treatments is influenced by the amount of water added and cooking time. The smaller the amount of water added, the higher the protein content. Table 1 shows that the best treatment for making saga seed milk is the addition of $150 \mathrm{~mL}$ of water and cooking time for 10 minutes.

\subsection{Viscosity}

The viscosity of saga seeds milk with various treatments can be seen in Table 2 . The longer the cooking time, the lower the viscosity. Increasing the amount of water from $150 \mathrm{ml}$ to $200 \mathrm{ml}$ will increase viscosity, but when the amount of water is added to $250 \mathrm{ml}$, the viscosity will decrease.

Table 2 The effect of cooking time and the amount of water added in making saga seed milk on viscosity

\begin{tabular}{cccc}
\hline \multirow{2}{*}{ Cooking time (min) } & \multicolumn{3}{c}{ Amount of water added (ml) } \\
\cline { 2 - 4 } & 150 & 200 & 250 \\
\hline 10 & $1,000 \pm 433.01$ & $1,083 \pm 144.34$ & $917 \pm 144.34$ \\
15 & $917 \pm 381.88$ & $1,000 \pm 250.00$ & $800 \pm 576.63$ \\
\hline
\end{tabular}

All values are means with \pm standard deviation $(\mathrm{n}=3)$

Viscosity is related to the thickness of a substance. The amount of water influences substances in the form of liquid viscosity value. The viscosity of certain drinking products is affected by free-flowing water. The addition of sugar to beverage products in addition to functioning as a flavor enhancer, nutrition, and increasing physiological role can also affect product quality [19]. The addition of sugar or honey in an emulsion drink can increase the level of creaming. 
Therefore the concentration of added sugar must be considered to produce an excellent product [20].

Viscosity testing needs to be done because the product made is intended as a drink so that what is desired is high emulsion stability. The thicker the emulsion, the stability will increase. The maximum product viscosity for drinks is 31.6 poise. If there is an increase in the beverage product's viscosity, it is generally not preferred by consumers less [21].

Based on the analysis of variance at the $95 \%$ confidence level, it shows that the amount of water added does not give a significant difference to the viscosity of saga seed milk.

\subsection{Organoleptic Value}

The hedonic test results can be seen in Table 3. Fresh milk is a highly nutritious food because it contains complete and balanced food substances such as protein, fat, carbohydrates, minerals, and vitamins needed by humans. Milk processing aims to obtain a variety of milk, high quality, high nutritional content, retention, facilitate marketing and transportation while increasing the exchange rate, and raw materials. Milk processing always develops in line with the development of science in the field of food technology.

\section{A. Color}

The color test results showed in Table 3. Based on color parameters, the highest score was saga seed milk with the addition of $150 \mathrm{ml}$ of water and cooked for 15 minutes with a strawberry flavor of $3.84 \pm 0.84$. Meanwhile, the one that received the lowest rating was saga seed milk with $150 \mathrm{ml}$ of water without cooking time and without the addition of flavorings, namely 1.46 \pm 0.58 .

The color of saga seeds milk in control is not preferred since it has a natural saga seeds milk. Color is one of the factors of food quality. Color is one part of product appearance and is an essential sensory rating parameter because of the nature of sensory assessment first seen by consumers [22]. Attractive food colors can influence and arouse consumer appetite; even food colors can be a clue to the quality of food produced [23]. 
Table 3 The Organoleptic Test of Saga Seeds Milk (Adenanthera pavonina)

\begin{tabular}{lcllccc}
\hline No. & $\begin{array}{c}\text { Water } \\
\text { Volume } \\
(\mathrm{mL})\end{array}$ & $\begin{array}{c}\text { Cooking } \\
\text { Process } \\
(\text { minute) }\end{array}$ & Flavors & Color & Aroma & Flavor \\
\hline 1. & 150 & - & - & $1.46 \pm 0.58$ & $1.42 \pm 0.54$ & $1.82 \pm 0.92$ \\
2. & 200 & - & - & $1.80 \pm 0.81$ & $1.42 \pm 0.54$ & $1.40 \pm 0.53$ \\
3. & 250 & - & - & $2.12 \pm 0.74$ & $1.62 \pm 0.64$ & $1.42 \pm 0.54$ \\
4. & 150 & 10 & Chocolate & $3.24 \pm 0.92$ & $2.36 \pm 0.94$ & $3.24 \pm 0.80$ \\
5. & 150 & 15 & Chocolate & $3.40 \pm 0.88$ & $2.78 \pm 0.84$ & $3.30 \pm 0.79$ \\
6. & 200 & 10 & Chocolate & $3.04 \pm 0.20$ & $2.96 \pm 0.35$ & $3.00 \pm 0.00$ \\
7. & 200 & 15 & Chocolate & $3.60 \pm 0.81$ & $3.20 \pm 0.95$ & $3.68 \pm 0.94$ \\
8. & 250 & 10 & Chocolate & $3.30 \pm 1.01$ & $3.58 \pm 0.97$ & $3.58 \pm 0.81$ \\
9. & 250 & 15 & Chocolate & $3.22 \pm 1.01$ & $3.52 \pm 1.01$ & $3.38 \pm 1.00$ \\
10. & 150 & 10 & Vanilla & $3.44 \pm 1.16$ & $3.20 \pm 1.26$ & $3.06 \pm 1.13$ \\
11. & 150 & 15 & Vanilla & $3.58 \pm 0.97$ & $3.26 \pm 1.05$ & $3.18 \pm 1.08$ \\
12. & 200 & 10 & Vanilla & $3.38 \pm 1.03$ & $3.58 \pm 0.93$ & $3.38 \pm 1.03$ \\
13. & 200 & 15 & Vanilla & $3.50 \pm 0.99$ & $3.70 \pm 0.95$ & $3.44 \pm 0.97$ \\
14. & 250 & 10 & Vanilla & $3.38 \pm 0.94$ & $3.60 \pm 0.86$ & $3.44 \pm 0.99$ \\
15. & 250 & 15 & Vanilla & $3.46 \pm 0.95$ & $3.70 \pm 0.97$ & $3.62 \pm 0.85$ \\
16. & 150 & 10 & Strawberry & $3.66 \pm 1.02$ & $3.64 \pm 1.08$ & $3.52 \pm 0.97$ \\
17. & 150 & 15 & Strawberry & $3.84 \pm 0.84$ & $3.58 \pm 1.07$ & $3.46 \pm 1.01$ \\
18. & 200 & 10 & Strawberry & $3.72 \pm 0.94$ & $3.96 \pm 0.90$ & $3.96 \pm 0.90$ \\
19. & 200 & 15 & Strawberry & $3.74 \pm 0.87$ & $3.76 \pm 0.91$ & $4.04 \pm 0.88$ \\
20. & 250 & 10 & Strawberry & $3.74 \pm 0.80$ & $3.72 \pm 0.81$ & $3.76 \pm 0.96$ \\
21. & 250 & 15 & Strawberry & $3.74 \pm 0.87$ & $3.66 \pm 0.85$ & $3.82 \pm 1.06$ \\
\hline
\end{tabular}

\section{B. Aroma}

Table 3 shows the treatment that produced saga seed milk with the highest aroma value was adding $200 \mathrm{ml}$ of water, cooked for 10 minutes, and the addition of strawberry flavor. This treatment's aroma score was $3.96 \pm 0.90$, while the lowest aroma value was found in saga seed milk with the treatment of an additional $150 \mathrm{ml}$ of water and $200 \mathrm{ml}$, uncooked treatment, and without the addition of flavor. The aroma score of these treatments were1.42 \pm 0.54 and $1.42 \pm$ 0.54 , respectively. Respondents do not prefer saga seeds milk on the aroma parameters for the control treatment.

Saga seed milk has a bad smell. One effort to eliminate this unpleasant odor is to use sodium bicarbonate $\left(\mathrm{NaHCO}_{3}\right)$ [24]. The processing of flavor enhancements in this study gives color to saga seeds milk to affect organoleptic testing.

The aroma is an essential indicator in the food industry because it can quickly provide a fair assessment of food products. In this study, the aroma was donated from a milk flavor enhancer.

\section{Flavor}

Based on the parameters of the saga seeds milk flavor that obtained the highest score, saga milk with the treatment of adding $200 \mathrm{ml}$ of water cooked for 15 minutes with the addition of strawberry flavor with a score of $4.04 \pm 0.88$ while the lowest was the saga seeds milk with the addition of $200 \mathrm{ml}$ of water. Without the treatment of cooking time and without the addition of flavor with a score of $1.4 \pm 0.53$. Similar to the aroma, from the assessment data, it can be said 
that respondents do not prefer the saga seeds milk on the flavor parameters for the control treatment.

Milk flavor/taste milk is a drink made from fresh milk, reconstituted milk or recombined milk with added flavor, can be added sugar, other food ingredients, and sterilized or pasteurized and hermetically packaged. Examples of chocolate-flavored milk/chocolate taste milk, strawberryflavored milk/strawberry taste milk [25]. While milk drinks are drinks made from fresh milk, reconstituted milk or recombined milk with or without added flavor or taste can be added sugar, other food ingredients, and sterilized or pasteurized and hermetically packaged.

Taste is a significant factor in determining the acceptance or rejection of food by consumers. The flavor produced is influenced by the components in food and the process they go through [26].

Taste is a very decisive factor in a consumer's final decision to refuse or accept food. Although the assessment parameters in terms of color and aroma are useful, if the taste of the food is not liked, then the product will be rejected by consumers or the public [27].

Acceptance of a product in the market is not only influenced by good product quality but is also influenced by the level of consumer preferences such as taste, aroma, texture, and color of the product [23]. Consumers prefer saga seeds milk with the addition of chocolate, vanilla, and strawberry flavors, so it can be developed into alternative milk, which is a source of protein derived from forestry plants.

\section{Conclusion}

In this study, processing treatments affect protein content and do not affect saga seed milk's viscosity. In organoleptic testing, the level of consumer preference for saga seeds milk with the addition of chocolate, vanilla, and strawberry flavors is preferred by consumers.

\section{Acknowledgment}

This research is PKM - Research at the Universitas Sumatera Utara sponsored by the Tanoto Foundation 2019.

\section{REFERENCES}

[1] Jaromin A, Korycińska M, Kozubek A, In Preedy, V.R., Watson, R.R., Patel, V.B. (Eds.), Coralwood (Adenanthera pavonina L.) Seeds and Their Protective E ect. Nuts and Seeds in Health and Disease Prevention, Academic Press, London, pp. 389-394, 2011.

[2] Sophy, A.J.R, Fleming, A.T., Vidhya, R., Shankar, K.G., Rajesh, B.N., "Cytotoxicity Assessment of Adenanthera pavonina Extracts in Brine Shrimp Larvae and Cancer Cell Lines," Inter J Vet Sci, vol. 5, no. 2, pp. 83-86. 2016. 
[3] Pandhare R., Sangameswaran B., "Extract of Adenanthera pavonina L. Seed Reduces Development of Diabetic Nephropathy in Streptozotocin-induced Diabetic Rats," Avicenna Journal of Phytomedicine, vol. 2, no. 4, pp. 233-242.

[4] Mujahid M.D., Vaseem A., Ansari, Sirbaiya A.K., Kumar R., Usmani A., "An Insight Of Pharmacognostic And Phytpharmacology Study Of Adenanthera pavonina," Journal Of Chemical And Phytopharmacology Study Of Adenanthera pavonina, vol. 8, no. 2, pp. 586-596. 2016.

[5] Tampubolon A., Mardiansyah M., Arlita T., "The Soaking of Saga Seed (Adenanthera Pavonina L.) with Various Coconut Water Concentration to Increase the Quality of the Sprout," Jom Faperta, vol. 3, no. 1, pp. 1-6. 2016.

[6] Ogbuagu M.N., Odoemelam S.A., "Fatty Acid and Amino Acid Profiles of an UnderUtilized Tropical African Seed: Adenanthera pavonina," The Pacific Journal of Science and Technology, vol. 14, no. 2, pp. 310-318.

[7] Hussain A., Rizvi I., Wahab S., Zareen I., Anshri S., Hussain M.S., "Antibacterial Screening Of The Bark Of Adenanthera pavonina (L)," International Journal of Biomedical Research, vol. 2, no. 2, pp. 110 122. 2011.

[8] Afolabi I.S., Nwachukwu I.C., Ezeoke C.S., Woke R.C., Adegbite O.A., Olawole T.D., Martins O.C., "Production Of A New Plant-Based Milk From Adenanthera pavonina Seed And Evaluation Of Its Nutritional And Health Benefits," Frontiers In Nutrition, vol. 5, no. 9, pp. 1-13. 2018.

[9] Mujahid M.D., Vaseem A., Ansari, Sirbaiya A.K., Kumar R., Usmani A., "An Insight Of Pharmacognostic And Phytpharmacology Study Of Adenanthera pavonina," Journal Of Chemical And Phytopharmacology Study Of Adenanthera pavonina, vol. 8, no. 2, pp. 586-596. 2016.

[10] Mumpuni D.E., "Potential of Saga Tree (Adenanthera pavonina) Seeds as a Substitution of Tempe Raw Materials (Protein Level Evaluation and Organoleptic Test)," Undergraduate Thesis, Universitas Negeri Semarang, Indonesia, 2010.

[11] Velmani S., Shanthi M., Chinniah C., Vellaikumar S., "Antimetabolic Effect on Spodoptera litura Due to Acute Feeding of Adenanthera pavonina Proteinase Inhibitor," International Journal of Chemical Studies, vol. 7, no. 4, pp. 980-986. 2019.

[12] Wardyaningrum D., "The Cognitive Level of Milk Consumption for Milkmaids in Lembang Jawa Barat," Al-Azhar Indonesia Social Institution Journal, vol. 1, no. 1, pp. 19-26. 2011.

[13] Ariyanto N.O., Wiyanto S.D., Hindarso H., Aylianawati, "Effect of Ratio Seed Mass, Water Volume, and Extraction Temperature to Seed Extraction in Vegetable Milk Processing," Jurnal Ilmiah Widya Teknik, vol. 14, no. 1, pp. 20-25. 2015.

[14] Anam C., Riyadi P.N.H., Nur S.A., "Application of Edible Cassava Flour Coating in Making Candy Saga (Adenanthera pavonina) on Sensory, Shelf Life, and Chemical Characteristics," Journal of Food Science and Technology, vol. 2, no. 3, pp. 23020733. 2013.

[15] Warsito, Suciyanti S.W., Isworo D., "Design and Analysis of Viscosity Measurement by Falling Ball Method Based on Optocoupler Sensor and Computer Acquisition System," Jurnal Natur Indonesia, vol. 14, no. 3, pp. 230-235. 2012.

[16] Meilgaard M., Civille, G., Carr B., Sensory Evaluation Tecniques, 4th ed., CRC Press, New Jersey, NJ USA, 2006.

[17] Afroz M.F., Anjum W., Nurulislam M., Kobiri M.A., Hossain K., Sayed A., "Preparation of soymilk using different methods," Journal of Food and Nutrition Science, vol. 4, no. 1, pp. 11-17. 2016.

[18] Nugraha A.Y.W., Seta F.T., "Milk Making Process from Saga Seeds (Adenanthera Pavonina) as Alternative for Cow Milk Protein and Soybean Milk," Undergraduate Thesis, Diponegoro University, Semarang, 2009.

[19] Fatimah F., Gugule S., Rindangen B., "Pharmaceutical Product Processing Technology Virgin Coconut Oil (VCO Emulsion with Fruit Flavored flavor) Derivative. Research Report," Research Collaboration Program Sam Ratulangi University and Palma Crop and Other Coconut Research Institute, Sam Ratulangi University, Manado, 2009. 
[20] Taherian A.R., Fustier P., Britten M., Ramaswamy H.S., "Steady and Dynamic Shear Rheological Properties and Stability of Non-Flocculated Beverage Emulsions," Int. J Food Properties, no. 10, pp. 1-20. 2007.

[21] Lyli M., Ohis N., Lahteenmaki L., Salmenkallio M., Liukkonen K.H., Karhunen K., Poutanen K., "The Effect of Fibre Amount, Energy Level and Viscosity of Beverages Containing Oat Fibre Supplement on Perceived Satiety," Food Nurt Res, no. 54, pp. 1654-6628. 2010.

[22] Rauf A., Pato U., Ayu D.F., "Antioxidant Activity and Panelist Reception of Avocado (Persea Americana Mill.) Leaf Powder Tea Based on Leaves on Twigs," Journal of the Faculty of Agriculture University of Riau, vol. 4, no. 2, pp. 1-12. 2017.

[23] Harahap R.D.J., "The Evaluation of Poliphenol Substance in Salak Seed Powdered Drink," Undergraduate Thesis, Faculty of Public Health, North Sumatra University, Medan, 2016.

[24] Randa A., Yusmarini, Zalfiatr Y., "Study of the Utilization of $\mathrm{NaHCO}_{3}$ in Making Tempe with Raw Materials for Jackfruit Seeds and Saga Seeds," Jom FAPERTA, vol. 4, no. 2, pp. 1-14. 2017.

[25] BPOM, "Regulation of the Head of the Drug and Food Control Agency about the Food Category," 2016.

[26] Setyaningsih D., Apriyantono A., Sari M.P., Sensory Analysis for the Food and Agro Industry, Bogor Agricultural Institute, Bogor, 2010.

[27] Saragih R., "Panelist Test on Torbangun (Coleus amboinicus) Tea Leaves," Widya E-Journal Health and Environment, vol. 1, no. 1, pp. 2338-7793. 2014. 